Ambiente \& Água - An Interdisciplinary Journal of Applied Science
ISSN 1980-993X - doi:10.4136/1980-993X
www.ambi-agua.net
E-mail: ambi-agua@agro.unitau.br

\title{
Drinking water quality assessment and corrosion mitigation in the hospital water supply system of Chacas Village (Peru)
}

\author{
doi: 10.4136/ambi-agua.1407 \\ Received: 30 May 2014; Accepted: 20 Jul. 2014

\section{Riccardo Bigoni $^{1}$; Sabrina Sorlini ${ }^{1 *}$; Maria Cristina Collivignarelli ; Paolo Berbenni ${ }^{3}+$} \\ ${ }^{1}$ University of Brescia, Brescia, Italy \\ Research Centre on Appropriate Technologies for Environmental Management in Developing Countries \\ ${ }^{2}$ University of Pavia, Pavia, Italy \\ Faculty of Engineering \\ ${ }^{3}$ Politecnico of Milano, Milano, Italy \\ *Corresponding author: e-mail: sabrina.sorlini@unibs.it, \\ ado.bigoni@gmail.com, mcristina.collivignarelli@unipv.it,
}

$\dagger$ Deceased

\begin{abstract}
Rural hospitals in developing countries often lack appropriate water treatments to assure their water needs. In these facilities, due to water different uses and its use with medical equipment, water quality problems can cause very hazardous situations. In particular, corrosion of water distribution systems is a common issue that can cause unwanted changes in water quality and failures of the distribution system's pipes. These considerations suggest that a complete monitoring program and water treatments to control and guarantee the water quality would be required in each health-care facility. This study assessed the quality of the water at the rural hospital of Chacas (Peru) as measured via specific physical-chemical and microbiological parameters. The results show that the chemical and microbiological qualities of the water generally worsen from catchment to the hospital's taps. Moreover, this work investigated the effects of a dolomite limestone filter installed to adjust the quality of the water distributed at the hospital and thereby mitigate the water's corrosiveness. Corrosion indices were calculated to provide useful information on the water's corrosiveness and positive results were obtained in reducing corrosiveness after the installation of the dolomite filter.
\end{abstract}

Keywords: Langelier saturation index (LSI), Ryznar stability index (RSI), dolomia filter.

\section{Avaliação de qualidade da água potável e diminuição da corrosão no sistema de fornecimento de água do hospital da vila Chacas (Peru)}

\section{RESUMO}

Muitas vezes, os hospitais rurais nos países em desenvolvimento carecem de tratamento adequado de água para assegurar o fornecimento. Nestas instalações, devido aos diferentes usos e aos equipamentos médicos, problemas na qualidade da água podem causar graves situações de risco. Em particular, a corrosão do sistema de distribuição de agua é um 
problema comum que pode causar alterações indesejadas na qualidade da água e falhas nos tubos do sistema de distribuição. Estas considerações sugerem que um programa de monitoramento completo e de tratamento de água para controlar e garantir a qualidade seria necessário em cada unidade de saúde. Este estudo descreve a avaliação da qualidade da água fornecida e distribuída no hospital rural de Chacas (Peru), com medidas de parâmetros físico-químicos e microbiológicos específicos. Os resultados mostram que a qualidade química e microbiológica da água geralmente piora da captação às torneiras do hospital. Além disso, este trabalho investigou o efeito do filtro de calcário dolomita instalado para diminuir a corrosividade da água e ajuste da qualidade da água distribuída no hospital. Os índices de corrosão foram calculados para fornecer informações úteis sobre a corrosividade da água e os resultados foram positivos para redução da corrosividade da água após a instalação do filtro dolomia.

Palavras-chave: índice de saturação Langelier (LSI), índice de estabilidade Ryznar (RSI), filtro dolomita.

\section{INTRODUCTION}

An important portion of the total burden of diseases worldwide is still attributable to unsafe water, inadequate sanitation or insufficient hygiene practices, especially in the rural areas of developing countries (Prüss-Üstün, 2011). Among basic services, health-care facilities are of utmost importance to improve and maintain the health of the local communities (WHO, 1988). Hospitals and clinics need an adequate water supply in order to guarantee water quantity and quality for human consumption, including hand washing, personal hygiene, medical procedures and equipment (e.g. patient care, cleaning and sterilization, laboratories, dental chairs, renal dialysis, etc.) (AWWA and CDC's, 2011). Moreover, in the water supply systems of these facilities, the presence of enteric pathogens originating externally released from corroded pipes and the growth of environmental microorganisms such as Legionella and Pseudomonas, represent significant water-related hazards, especially due to the different water uses involved and the vulnerability of some patients (Cunliffe et al., 2011). Therefore, water quality problems are related to microbiological and chemical contaminants that may occur because of water source contaminations or water system deteriorations (Lee and Schwab, 2005). For these reasons, the optimization of technical solutions for improving water quality as well monitoring programs should be performed routinely to prevent and limit any hazardous situations (WHO, 2011). As already mentioned, an important issue related to water quality in water supply systems is the partial deterioration of pipes resulting from corrosion reactions (USEPA, 1984). A series of electrochemical reactions occur on the pipe surfaces in contact with water and may lead to structural failures and alteration of microbiological and chemical water quality, including exceeding guideline values for lead, copper and iron (WHO, 2006). Moreover, corrosion can influence the organoleptic properties of water and the costs of providing safe water to the final users (Volk et al., 2000). Several factors, such as the type of materials, pipe ages, stagnation time and physical-chemical composition of water can cause pipe corrosion. In particular, corrosion processes can be influenced by the interactions of chemical proprieties (e.g. $\mathrm{pH}$, alkalinity, dissolved oxygen, total hardness, etc.) and physical characteristics (temperature, flow, velocity) of distributed water (Health Canada, 2009). For these reasons, an important role, especially for facilities with high standards or hygiene, such as health-care facilities, is played by a water quality control program that provides valuable corrosion-related information and, where necessary, by a water treatment system to reduce water corrosiveness (Cunliffe et al., 2011). An affordable and widely applied strategy to make water "noncorrosive" is to modify water quality through $\mathrm{pH}$ and total alkalinity adjustment (Vik et al., 
1996). Through the $\mathrm{pH}$ and total alkalinity manipulation, in fact, calcium carbonate $\left(\mathrm{CaCO}_{3}\right)$ can precipitate to form a protective film on the interior pipe surfaces, which provides sufficient corrosion protection (AWWA, 1978). Therefore, the water $\mathrm{pH}$ and its relationship with other water quality parameters play an important role for the solubility of $\mathrm{CaCO}_{3}$ (USEPA, 1984). However, for a successful deposition of $\mathrm{CaCO}_{3}$ film, the water must have the proper $\mathrm{pH}$ value and must contain enough $\mathrm{Ca}^{2+}$ and $\mathrm{HCO}_{3}{ }^{-}$ions (Shams El Din, 2009). In small water systems with low-alkalinity waters, a common option to "manipulate" water parameters for corrosion mitigation is the application of the alkaline media filters (Vik et al., 1996).

This study assessed the quality of water at the "Mama Ashu" hospital of Chacas Village (Peru) and monitored the effects of a dolomite limestone filter installed to raise the $\mathrm{pH}$ in order to mitigate the water corrosiveness. Specific objectives of this study were: to assess physical, chemical and microbiological quality of the water supplied to the hospital according to World Health Organization guidelines (WHO, 2011) and Peruvian water quality regulation (Peru, 2011); to investigate the status of the water supply system of the hospital and to determine water quality changes after the alkaline media filter using a limited number of significant parameters and corrosion indices that can be exploited to evaluate water corrosiveness.

\section{MATERIALS AND METHODS}

\subsection{The hospital water supply system}

This study was carried out in "Mama Ashu" hospital located in Chacas, an Andean village in the Ancash region of Peru, at 3,336 meters above sea level. This hospital serves the entire province of Chacas, which has about 10,000 inhabitants (Asuncin, 2007). The hospital building has two floors four wards (40 beds), a dispensary, two operating rooms, a delivery room, two dental units, a medical laboratory and other services (e.g. laundry, kitchen, toilets, showers, etc.). The hospital, constructed in 1994, has its own water supply system due to several failures (intermittences, low water pressure, etc.) and changes in water quality distributed by the public water supply system of the Chacas village.

A complete water system scheme is presented in Figure 1a.

The hospital water supply system is a gravity-fed system and has five spring catchments (S1, S2, S3, S4, and S5) located between 3,850 and 4,000 meters above sea level. The total flow-rate is of about $1 \mathrm{~L} \mathrm{~s}^{-1}$ and the difference in altitude between the catchments and the hospital building is 700 meters. A 2 inch PVC transmission line, 5,000 meters long, connects the springs with the hospital. In this line, three break-pressure tanks (BPT1, BPT2, and BPT3), with a volume of $1 \mathrm{~m}^{3}$ each one, realign the water pressure in the pipeline with atmospheric pressure. A concrete storage tank (ST) with a volume capacity of $50 \mathrm{~m}^{3}$ is located near the hospital building and ensures the water quantity needed for the hospital's daily consumption. Before this tank, the transmission line is connected to a limestone filter that was installed as a corrosion mitigation treatment during this study. Inside the hospital building, the water distribution system is made up of galvanized steel pipes with diameters from $1 / 2$ inch to 2 inches.

The main water uses (total daily consumption close to $25 \mathrm{~m}^{3}$ ) in the "Mama Ashu" hospital are: drinking and food preparation, patients' baths and personal hygiene, laundry services, flushing of toilets, fire prevention system, laboratory services, and cleaning. In order to fully investigate the water system conditions, many inspections of the installations were performed to control the status of the infrastructures, to identify possible hygiene risks and to evaluate operation and maintenance activities. Direct interviews with the hospital director and 
maintenance operators were carried out to investigate equipment and infrastructure conditions.

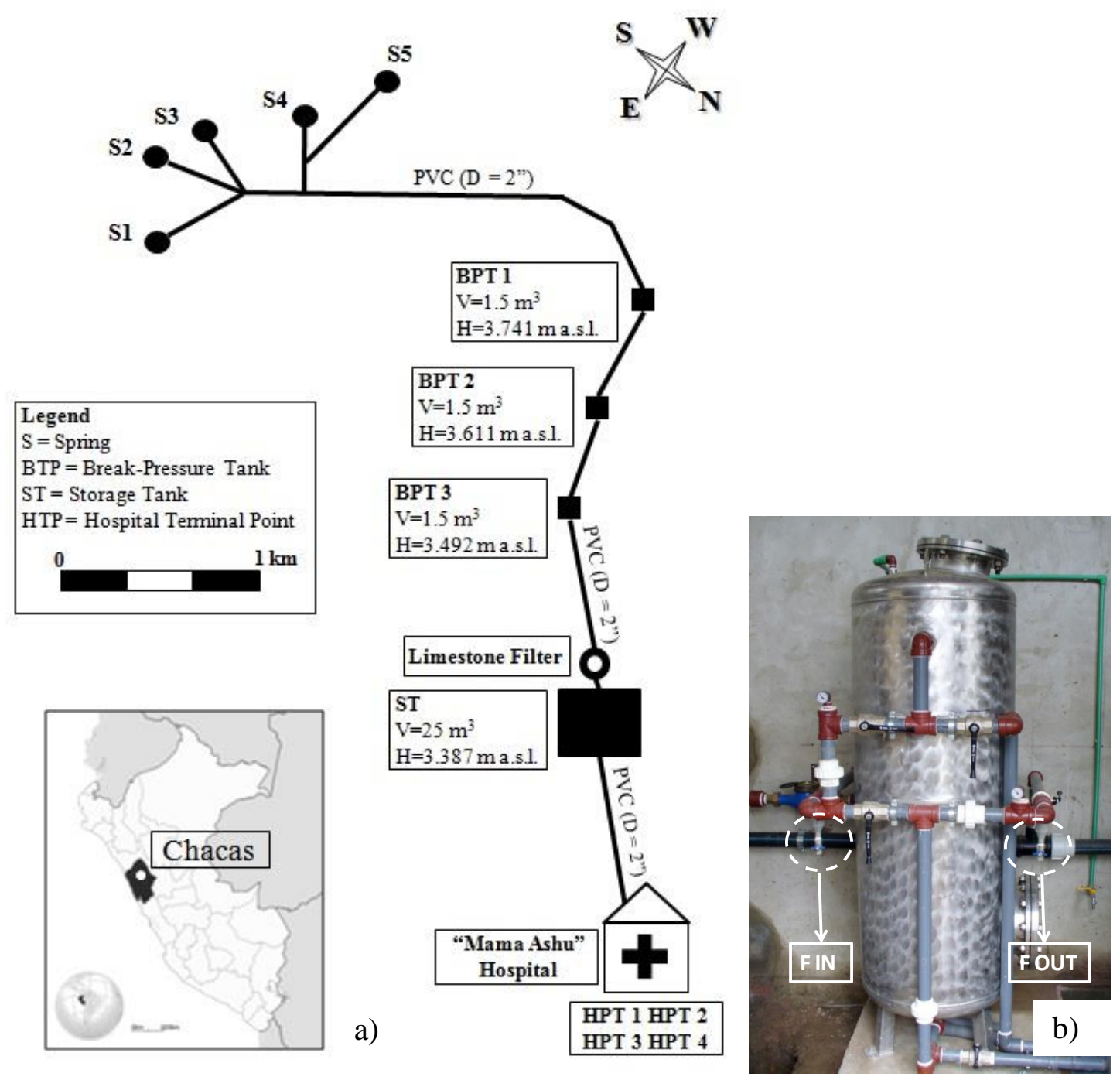

Figure 1. Scheme of the hospital water supply system and the sampling points (a) and limestone filter installed in the hospital water supply system (b).

\subsection{The limestone filter}

The filter is a stainless steel tank $(1.5 \mathrm{~m}$ high and an internal diameter of $0.75 \mathrm{~m})$ with water inlet and outlet pipes ( 1 inch diameter) on the top and on the bottom part of the tank, respectively (Figure 1b). Before and after the filter two taps were installed to collect water samples. The dolomite limestone media in the filter (Dolomite, Kalki, Italy) has an effective size between 1.60 and $2.10 \mathrm{~mm}$, a density of $1,200 \mathrm{~kg} \mathrm{~m}^{-3}$ and the following mineral analysis (in weight): $\mathrm{SiO}_{2}=0.12 \%, \mathrm{Fe}_{2} \mathrm{O}_{3}=0.016 \%, \mathrm{MgCO}_{3}=5.60 \%, \mathrm{CaO}_{3}=44.2 \%$. The depth of the dolomite layer $\left(0.9 \mathrm{~m}\right.$ with a volume of $\left.0.4 \mathrm{~m}^{3}\right)$ was calculated in order to keep the water inside the filter for the time ( 10 minutes) required to increase the $\mathrm{pH}$ of raw water to $\mathrm{pH}=8$, necessary to allow the $\mathrm{CaCO}_{3}$ deposition on the internal pipes surfaces and, therefore, to prevent pipe corrosion. Calculation of the theoretical contact time and of the minimum material volume was performed following the German Gas and Waterworks Association guidelines for designing alkaline media filters (DVGW, 1993). In addition, the amount of media dissolved during the filter operation, calculated based on the acidity of the raw water was roughly $20 \mathrm{~kg}$ per month. Thus, the total height of the media resulted to be $1.00 \mathrm{~m}$ 
considering the high of $0.9 \mathrm{~m}$ plus the amount of dolomia consumed during the filter operation (monthly consumption of $20 \mathrm{~kg}$ ) and the amount lost during the filter backwashing. Dolomia was supported by a layer $(50 \mathrm{~kg}, 0.3 \mathrm{~m}$ high) of crushed quartzite. The filter operated in downflow conditions and was equipped with an upflow backwash system to keep the media clean during its operation.

\subsection{Water quality: physical and chemical analysis}

During the monitoring campaign (March - May), water samples were collected from the five springs (S1, S2, S3, S4 and S5), from the three break-pressure tanks (BPT1, BPT2, and BPT3), before and after the filter (F IN and F OUT), from the storage tank (ST) and from four different terminal taps placed on the distribution system (HTP1, HTP2, HTP3, and HTP4) inside the hospital. Each water sample, collected in pre-washed polyethylene bottles with a volume of 1.5 litres, was collected five times during the monitoring campaign. Temperature, $\mathrm{pH}$, conductivity and turbidity were measured with portable instruments (WTW Multi 3400i and Turb 350 IR, WTW Wissenschaftlich-Technische Werksttten GmbH, D) during water sampling. The determination of the major ions and other chemical properties was performed on the same day of sampling in a hospital room equipped with laboratory instruments. Total alkalinity with $\mathrm{HCl} 0.1 \mathrm{~N}$, chlorides with $\mathrm{AgNO}_{3} 0.1 \mathrm{~N}$, sulphates, calcium and total hardness with $0.1 \mathrm{~N}$ EDTA were determined by titration methods using APHA standard methods procedures (APHA, 1998). A colorimetric water test kit (Visocolor HE Iron, Macherey-Nagel $\mathrm{GmbH}$ and Co., D) was used to measure iron concentration in water samples.

\subsection{Water quality: microbiological analysis}

Water samples for microbiological analysis were collected using sterile $500 \mathrm{~mL}$ bottles at the same water points analysed for the physical-chemical analysis. After sampling, the bottles were immediately closed and transported to an equipped laboratory in a hospital room and stored at $4{ }^{\circ} \mathrm{C}$ until being analysed. The quantification of total coliforms, Escherichia coli, Streptococchi faecalis and Pseudomonas aeruginosa in water samples was done with the membrane filtration technique using portable microbiological laboratory (Trawas, Sandberg and Schneidewind, D). This method, commonly used in the field, consists of the water sample filtration through a $0.45 \mu \mathrm{m}$ membrane filter (MCE Membrane Filter, Advantec MFS, CA) and the development of bacteria colonies in a favourable environment at controlled temperature of $37^{\circ} \mathrm{C}$ for 24 or $48 \mathrm{~h}$ (WHO, 2011; USEPA, 1984).

\subsection{Water corrosiveness}

Water corrosiveness depends on water physical and chemical characteristics and on the type of the pipe materials. However, it can be predicted by means of "corrosion indices", calculated on the principle of calcium carbonate deposition. Langelier Saturation Index (LSI) (Langelier, 1936) and Ryznar Saturation Index (RSI) (Ryznar, 1944) are the main qualitative $\mathrm{CaCO}_{3}$ saturation indices available to determine whether water has a tendency to precipitate $\mathrm{CaCO}_{3}$ (water supersaturated) or to dissolve it (water under-saturated). Usually,supersaturated water is scale-forming water and under-saturated is not (Reddy and Nancollas, 1976). Nevertheless, these two indices do not provide an indication of how much calcium carbonate will precipitate to bring water to equilibrium (USEPA, 1984), they simply indicate the driving force for scale formation that depends on temperature, $\mathrm{pH}$, concentrations of $\mathrm{HCO}_{3}{ }^{-}, \mathrm{CO}_{2}{ }^{3-}$, $\mathrm{Ca}^{2+}$ and $\mathrm{Mg}^{2+}$ ions (Al-Rawajfeh and Al-Shamaileh, 2007).

Langelier Saturation Index is defined as LSI=pH-pHs and Ryznar Saturation Index is defined as $\mathrm{RSI}=2 \mathrm{pHs}-\mathrm{pH}$ where $\mathrm{pH}$ is water $\mathrm{pH}$ and $\mathrm{pHs}$ is the saturation $\mathrm{pH}$ at the calcium carbonate equilibrium. The $\mathrm{pHs}$ can be determined as $\mathrm{pHs}=\mathrm{pK} 2-\mathrm{pKsp}+\mathrm{pTA}+\mathrm{p}\left[\mathrm{Ca}^{2+}\right]$ where $\mathrm{K} 2$ is the second dissociation constant of carbonic acid, Ksp is the solubility product of calcium carbonate, TA is total alkalinity and $\left[\mathrm{Ca}^{2+}\right]$ is the concentration of calcium ions. The 
p-function assigns the negative logarithm of that variable (Al-Rawajfeh and Al-Shamaileh, 2007). If water has a negative LSI value, it is under-saturated with respect to calcium carbonate and is potentially corrosive. Conversely, for waters with a positive LSI, a protective layer of calcium carbonate can be formed as the water is supersaturated with $\mathrm{CaCO}_{3}$ and the water is scaling. Saturated water has a LSI of zero. If water has an RSI value between 6 and 7, the water has the potential of light scale or corrosion. At less than 6 , the water is scale forming, and at higher than 7, the water is corrosive. LSI and RSI indices for the evaluation of pipe corrosion potential were calculated for each water point analysed in the hospital water supply system for the physical-chemical analysis.

\section{RESULTS AND DISCUSSION}

\subsection{Physical and chemical characteristics}

The physical and chemical properties of the water samples including $\mathrm{pH}$, temperature, electrical conductivity, turbidity, total alkalinity (bicarbonates), chlorides, sulphates, calcium, total hardness and iron are shown in Table 1. The values presented are the average of the results obtained by five different measurements for each sampling point.

Table 1. Physical-chemical parameters of water distributed in Chacas hospital supply system (S: Spring; BPT: Break Pressure Tank; F: Filter; ST: Storage Tank; HTP: Hospital Terminal Point).

\begin{tabular}{|c|c|c|c|c|c|c|c|c|c|c|}
\hline Sampling point & $\begin{array}{c}\mathrm{T} \\
{ }^{\circ} \mathrm{C}\end{array}$ & $\begin{array}{c}\mathrm{pH} \\
-\end{array}$ & $\begin{array}{c}\mathrm{EC} \\
\mu \mathrm{S} \mathrm{cm}^{-1}\end{array}$ & $\begin{array}{c}\text { Turbidity } \\
\text { NTU }\end{array}$ & $\begin{array}{l}\mathrm{HCO}_{3}^{-} \\
\mathrm{mg} \mathrm{L}^{-1}\end{array}$ & $\begin{array}{c}\mathrm{Cl}^{-} \\
\mathrm{mg} \mathrm{L}^{-1}\end{array}$ & $\begin{array}{l}\mathrm{SO}_{4}^{2-} \\
\mathrm{mg} \mathrm{L}^{-1}\end{array}$ & $\begin{array}{l}\mathrm{Ca}^{2+} \\
\mathrm{mg} \mathrm{L}^{-1}\end{array}$ & $\begin{array}{c}\mathrm{TH} \\
\mathrm{mg} \mathrm{L}^{-1}\end{array}$ & $\begin{array}{c}\mathrm{Fe}^{2+} \\
\mathrm{mg} \mathrm{L}^{-1}\end{array}$ \\
\hline \multicolumn{11}{|l|}{ Springs } \\
\hline S 1 & 9.4 & 6.4 & 107.4 & 0.03 & 32.5 & 17.3 & 13.2 & 8.8 & 49 & 0.01 \\
\hline S 2 & 9.3 & 6.2 & 85.5 & 1.21 & 25.3 & 18.7 & 11.1 & 6.1 & 43 & 0.02 \\
\hline S 3 & 9.7 & 6.8 & 89.5 & 1.07 & 25.1 & 16.2 & 10.4 & 5.8 & 41 & 0.01 \\
\hline S 4 & 10.1 & 6.2 & 99.5 & 0.24 & 22.5 & 18.6 & 10.5 & 7.6 & 45 & 0.01 \\
\hline S 5 & 10.2 & 6.6 & 100.2 & 0.67 & 22.8 & 19.4 & 12.2 & 7.2 & 44 & 0.02 \\
\hline \multicolumn{11}{|l|}{ Transmission } \\
\hline BPT 1 & 11.2 & 6.7 & 108.5 & 1.07 & 26.1 & 14.1 & 12.7 & 8.1 & 47 & 0.01 \\
\hline BPT 2 & 12.4 & 6.5 & 109.7 & 1.17 & 25.4 & 19.5 & 11.2 & 10.2 & 46 & 0.01 \\
\hline BPT 3 & 13.2 & 6.7 & 108.4 & 1.23 & 27.8 & 17.8 & 11.7 & 9.8 & 45 & 0.01 \\
\hline \multicolumn{11}{|l|}{ Filter } \\
\hline F IN & 12.8 & $6.7 *$ & 106.6 & 1.51 & 26.3 & 18.4 & 12.4 & 8.8 & 46 & 0.02 \\
\hline F OUT & 13.0 & $7.6^{*}$ & 112.4 & 1.94 & 36.1 & 18.9 & 12.6 & 11.4 & 51 & 0.01 \\
\hline \multicolumn{11}{|l|}{ Distribution } \\
\hline ST & 13.5 & 7.8 & 114.5 & 1.81 & 35.3 & 19.3 & 9.7 & 11.7 & 53 & 0.02 \\
\hline HTP 1 & 12.8 & 7.6 & 112.9 & 2.33 & 38.6 & 14.2 & 12.8 & 10.2 & 51 & 0.07 \\
\hline HTP 2 & 12.8 & 7.7 & 109.9 & 2.81 & 33.5 & 16.9 & 12.3 & 10.0 & 49 & 0.11 \\
\hline HTP 3 & 13.4 & 7.6 & 116.6 & 1.74 & 39.3 & 18.1 & 15.7 & 11.1 & 50 & 0.08 \\
\hline HTP 4 & 13.2 & 7.5 & 113.4 & 2.04 & 37.5 & 17.5 & 20.8 & 10.8 & 50 & 0.10 \\
\hline $\begin{array}{l}\text { Peru (2011) } \\
\text { DS N } 031-2010-S A\end{array}$ & - & $\begin{array}{l}6.5- \\
8.5\end{array}$ & 1,500 & 5 & - & 250 & 250 & - & 500 & 0.3 \\
\hline
\end{tabular}

(*) These values represent the averages of 15 measurements. 
The $\mathrm{pH}$ values ranged from 6.2 to 6.8 in the samples collected from the springs and along the transmission line. The $\mathrm{pH}$ values of samples taken before and after the limestone filter during the monitoring campaign are presented in Figure 2. The dolomite limestone dissolution increased the $\mathrm{pH}$ of an average of 0.9 units and the $\mathrm{pH}$ of the filter effluent was close to the target value of 8 to enhance corrosion control. The $\mathrm{pH}$ levels in the samples collected inside the hospital building were influenced by filter and were always within WHO (2011) optimum range $(6.5-8.5)$. The electrical conductivity ranged from 85.5 to $116.6 \mu \mathrm{S} \mathrm{cm}^{-1}$, thus within the WHO standard (2011). The increase of conductivity after the filter and in the distribution system may have been caused by the dissolution of the dolomite limestone.

All the samples analyzed showed turbidity values lower than WHO limit (5 NTU). The results indicated that water from the hospital internal water distribution system (HTP1, 2, 3 and 4) had higher turbidity values than in the transmission line, probably due to the presence of corrosion products such as particles of iron (hydroxide, carbonate, oxide) derived from the steel pipes of the internal distribution system.

Total alkalinity is the sum of carbonates and bicarbonates; the values of bicarbonates are generally used to express alkalinity in absence of carbonates $(\mathrm{pH}<8.5)$. For the water samples analyzed, alkalinity was between 22.5 and $39.3 \mathrm{mg} \mathrm{L}^{-1}$ and the limestone filter increased alkalinity from 26.3 to $36.1 \mathrm{mg}\left(\mathrm{HCO}_{3}{ }^{-}\right) \mathrm{L}^{-1}$ due to the dissolution of dolomite.

Chloride and sulphate concentrations ranged from 14.1 to $19.5 \mathrm{mg} \mathrm{L}^{-1}$ and from 9.7 to $20.8 \mathrm{mg} \mathrm{L}^{-1}$ respectively and were always lower than WHO limits for drinking water (2011).

The concentrations of calcium ions in the water samples ranged from 5.8 to $11.7 \mathrm{mg} \mathrm{L}^{-1}$ while total hardness ranged from 41 to $53 \mathrm{mg} \mathrm{L}^{-1}$. Both of them had values within the WHO (2011) standard and were increased by the dolomite limestone dissolution.

Iron concentrations were very low, ranging from 0.01 to $0.11 \mathrm{mg} \mathrm{L}^{-1}$ and it seemed to increase slightly in the terminal points of the hospital distribution system. The concentration of iron was also measured because it is an important index for evaluating the state of corrosion of metal pipes. Generally, the physical and chemical characteristics of water sampled in the water supply system were always within WHO guidelines standards (2011) and Peruvian regulation (Peru, 2011).

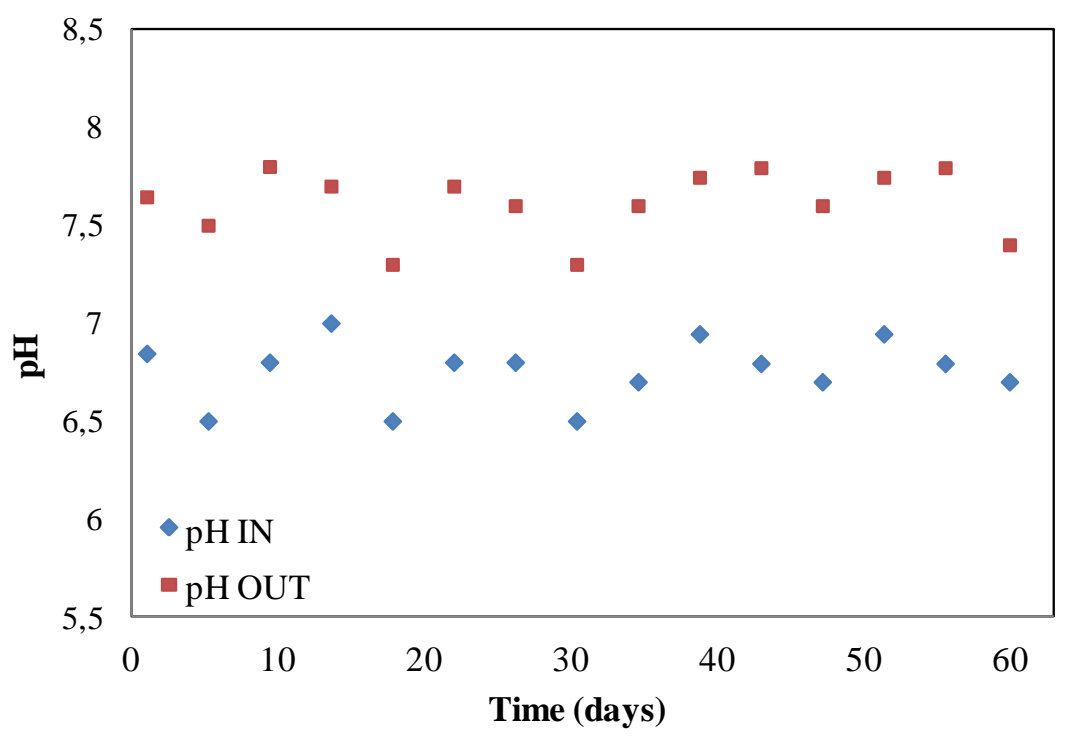

Figure 2. The $\mathrm{pH}$ values (15) before and after the limestone filter measured during the monitoring campaign. 


\subsection{Microbiological characteristics}

The most common health risk associated with drinking-water comes from fecal contamination that can be measured by means of microbiological analysis. Total coliforms, Escherichia coli, Streptococchi faecalis and Pseudomonas aeruginosa were analyzed and the results are presented in Table 2. The results indicated that water springs were not polluted since the concentration of Escherichia coli, used as an indicator of fecal contamination, was always 0 CFU $100 \mathrm{~mL}^{-1}$. In the sample points along the transmission line, before and after the limestone filter and in the hospital distribution system, the concentrations of fecal indicators bacteria were slightly higher than in the springs. Moreover, the number of Escherichia Coli occurred mainly in the hospital terminal points rather than along the water transmission line and the level of contamination slightly exceed the WHO standard (WHO, 2011; Peru, 2011). This health hazard was probably due to the lack of a disinfection treatment before water distribution in the hospital building. The number of Pseudomonas aeruginosa, used as indicator of microbial regrowth in the internal plumbing system, was always low. Furthermore, Pseudomonas aeruginosa was measured because it is among the most relevant health-care-associated pathogens identified in distributed water (WHO, 2011).

Table 2. Microbiological analysis of water distributed in Chacas hospital supply system (S: Spring; BPT: Break Pressure Tank; F: Filter; ST: Storage Tank; HTP: Hospital Terminal Point).

\begin{tabular}{ccccc}
\hline & Total & Escherichia & Streptococchi & Pseudomonas \\
Sampling point & coliforms & Coli & faecalis & aeruginosa \\
& CFU $100 \mathrm{~mL}^{-1}$ & CFU $100 \mathrm{~mL}^{-1}$ & ${\mathrm{CFU} 100 \mathrm{~mL}^{-1}}_{\mathrm{CFU} 100 \mathrm{~mL}^{-1}}$ \\
\hline
\end{tabular}

\begin{tabular}{|c|c|c|c|c|}
\hline \multicolumn{5}{|l|}{ Springs } \\
\hline S 1 & 0 & 0 & 2 & 0 \\
\hline S 2 & 2 & 0 & 0 & 1 \\
\hline S 3 & 3 & 0 & 1 & 4 \\
\hline S 4 & 0 & 0 & 0 & 0 \\
\hline S 5 & 1 & 0 & 0 & 1 \\
\hline \multicolumn{5}{|l|}{ Transmission } \\
\hline BPT 1 & 2 & 1 & 1 & 0 \\
\hline BPT 2 & 0 & 0 & 1 & 3 \\
\hline BPT 3 & 4 & 0 & 0 & 1 \\
\hline \multicolumn{5}{|l|}{ Filter } \\
\hline F IN & 3 & 0 & 1 & 0 \\
\hline F OUT & 3 & 1 & 0 & 0 \\
\hline \multicolumn{5}{|l|}{ Distribution } \\
\hline ST & 4 & 2 & 2 & 3 \\
\hline HTP 1 & 6 & 1 & 4 & 1 \\
\hline HTP 2 & 4 & 5 & 3 & 1 \\
\hline HTP 3 & 9 & 3 & 5 & 0 \\
\hline HTP 4 & 5 & 2 & 0 & 0 \\
\hline $\begin{array}{l}\text { Peru (2011) } \\
\text { DS N }{ }^{\circ} 031-2010-S A\end{array}$ & 0 & 0 & - & - \\
\hline
\end{tabular}




\subsection{Status of the hospital water supply system and corrosion monitoring}

The status of the hospital water supply system was evaluated by means of site visits and interviews with hospital director and maintenance operators. The spring catchments, the break pressure tanks and the storage tanks are periodically controlled and cleaned and the transmission pipe is always maintained buried. The alkaline filter is periodically controlled, refilled monthly with new media and cleaned through the backwash system. In the hospital internal distribution system, several signs of corrosion on the pipe surfaces were noticed and red water production was observed when tap water was not collected for some days. Many holes in the pipes' surfaces were repaired by the operators during the previous years.

Moreover, a monitoring campaign of the physical and chemical water characteristics was conducted in order to determine the precipitation tendency of the distributed water and to assess the correct operation of the limestone filter. For this reason, the values of Langelier Saturation Index (LSI) and Ryznar Stability Index (RSI) were calculated for each sampling point. The results are reported in Table 3.

LSI values were always negative and ranged from - 1.04 in the storage tank (ST) to - 3.07 in the spring S2. RSI values ranged from 10.04 in the hospital terminal point (HTP 3) to 12.34 in the spring S2. The water samples collected at the springs and along the transmission line indicated an average of LSI values of -2.8 and of RSI values of 11.8. Results revealed that both LSI and RSI values of the water samples analyzed after the filter showed the tendency to reach the water saturation status in order to form protective scale layers inside the pipes. The limestone filter modified both the LSI and RSI to values of - 1.2 and 10.0, respectively. These values indicated a positive effect of the filter on the corrosion tendency of the water distributed. Therefore, the LSI and RSI indices were useful tools for pipe corrosion evaluation even if both LSI and RSI were not suitable for the quantification of water corrosiveness.

Table 3. LSI and RSI values of water distributed in Chacas hospital supply system (S: Spring; BPT: Break Pressure Tank; F: Filter; ST: Storage Tank; HTP: Hospital Terminal Point).

\begin{tabular}{lccc}
\hline Sampling point & pHs & LSI & RSI \\
\hline Springs & & & \\
S 1 & 9.00 & -2.60 & 11.61 \\
S 2 & 9.27 & -3.07 & 12.34 \\
S 3 & 9.30 & -2.50 & 11.80 \\
S 4 & 9.23 & -3.03 & 12.26 \\
S 5 & 9.24 & -2.64 & 11.89 \\
Transmission & & & \\
BPT 1 & 9.13 & -2.43 & 11.57 \\
BPT 2 & 9.04 & -2.54 & 11.59 \\
BPT 3 & 9.02 & -2.32 & 11.35 \\
Filter & & & \\
F IN & 9.09 & -2.39 & 11.49 \\
F OUT & 8.84 & -1.24 & 10.09 \\
Distribution & & & \\
ST & 8.84 & -1.04 & 9.89 \\
HTP 1 & 8.86 & -1.26 & 10.13 \\
HTP 2 & 8.93 & -1.23 & 10.17 \\
HTP 3 & 8.82 & -1.22 & 10.04 \\
HTP 4 & 8.85 & -1.35 & 10.21 \\
\hline
\end{tabular}




\section{CONCLUSION}

The results show that the physical and chemical characteristics of the water supplied and distributed in the hospital are always below those permitted by Peruvian regulation and by WHO guidelines values for drinking water. Water turbidity and iron concentration increase in the hospital distribution system due to pipe corrosion and was confirmed by specific corrosion indices.

Microbiological analyses show a low sanitary risk that is not irrelevant if we consider the type of building. Escherichia Coli and Streptococci faecalis concentration seems to rise slightly in the hospital distribution system. In order to ensure a safe quality to the delivered water, a water disinfection treatment should be installed. The hospital water supply system is in good condition except for some signs of corrosion (holes in surface pipes or red water production).

The alkaline filter, installed to mitigate corrosion, changed some physical-chemical parameters due to the dissolution of dolomite media. In fact, LSI and RSI values calculated for treated water confirmed the reduction of water corrosiveness after filtration. Furthermore, compared to conventional chemical addition, a limestone contactor is easier and safer to operate, reduces operating costs, self-adjusts the water $\mathrm{pH}$ without risk of chemical overdose, requires minimal maintenance and operator skill, and does not require continuous feed of chemicals. Finally, the water quality monitoring program applied in this study was found to be effective for the evaluation of water corrosiveness characteristics and is recommended as a protocol for water quality monitoring to be regularly applied.

\section{ACKNOWLEDGEMENTS}

Riccardo Bigoni developed this project during his $\mathrm{PhD}$ studies in Appropriate Methods and Technologies for International Development Co-operation, supported by the Alberto Archetti Funds. Sabrina Sorlini and Maria Cristina Collivignarelli coordinated the data processing and the discussion. Riccardo Bigoni performed the described monitoring campaign, data processing and discussion. The authors wish to thank Prof. Paolo Berbenni (Politecnico di Milano) for his assistance and Operazione Mato Grosso NGO (Brescia, IT) for the collaboration in the research activities.

\section{REFERENCES}

AL-RAWAJFEH, A. E.; AL-SHAMAILEH, E. M. Assessment of tap water resources quality and its potential of scale formation and corrosivity in Tafila province, South Jordan. Desalination, v. 206, n. 1-3, p. 322-332, 2007.

http://dx.doi.org/10.1016/j.desal.2006.01.039

AMERICAN PUBLIC HEALTH ASSOCIATION - APHA. Standard methods for the examination of water and wastewater. $20^{\text {th }} \mathrm{Ed}$. Washington, 1998.

AMERICAN WATER WORKS ASSOCIATION - AWWA. Corrosion control by deposition of $\mathrm{CaCO}_{3}$ films. Denver, 1978.

AMERICAN WATER WORLD ASSOCIATION - AWWA; UNITED STATES. Department of Health and Human Services. Centers for Deseases Control And Preventions CDC's. Emergency water supply planning guide for hospitals and health care facilities. Atlanta, 2011. 
ASUNCIN. Municipalidad Provincial. Plan vial provincial participativo, municipalidad provincial de Asuncin. Chacas, 2007.

CUNLIFFE, D.; BARTRAM, J.; BRIAND, E.; CHARTIER, Y.; COLBOURNE, J.; DRURY, D. et al. Water safety in buildings. Geneva: World Health Organization, 2011.

DEUTSCHER VEREIN DES GAS- UND WASSERFACHS - DVGW. Water treatmentdeacidification of water: basics for planning, design and operation of filters. Bonn, 1993.

HEALTH CANADA. Guidance on controlling corrosion in drinking water distribution systems. Ottawa, 2009.

LANGELIER, W. F. The analytical control of the anticorrosion water treatment. Journal of American Water Works Association, v. 28, n. 10, p. 1500-1521, 1936. http://www.jstor.org/stable/41226418

LEE, E. J.; SCHWAB K. J. Deficiencies in drinking water distribution systems in developing countries. Journal of Water \& Health, v. 3, n. 2, p. 109-127, 2005.

PERU. Ministerio de Salud - MINSA. Direccion general de salud ambiental DS $\mathbf{n}^{\circ} 031$ 2010-SA. Regolamento de la calidad del agua para consumo humano. Lima, 2011.

PRÜSS-ÜSTÜN, A.; BOS, R.; GORE, F.; BARTRAM, J. Safer water, better health: costs, benefits and sustainability of interventions to protect and promote health. Geneva: World Health Organization, 2011.

REDDY, M. M.; NANCOLLAS, G. H. The crystallization of calcium carbonate. Journal of Crystal Growth, v. 37, n. 4, p. 824 - 830, 1976. http://dx.doi.org/10.1016/00219797(71)90161-5

RYZNAR, J. W. A new index for determining amount of calcium carbonate scale formed by a water. Journal of American Water Works Association, v. 36, n. 4, p. 472-486, 1944.

SHAMS EL DIN, A. M. Three strategies for combating the corrosion of steel pipes carrying desalinated potable water. Desalination, v. 238, p. 166-173, 2009. http://dx.doi.org/10.1016/j.desal.2007.11.063

UNITED STATES. Environmental Protection Agency - USEPA. Corrosion manual for internal corrosion of water distribution systems. Washington, 1984.

VIK, E. A.; RYDER, R. A.; WAGNER, I.; FERGUSON, J. F. Mitigation of corrosion effects. In: AMERICAN WATER WORKS ASSOCIATION; DVGW TECHNOLOGIEZENTRUM WASSER. Internal corrosion of water distribution systems. $2^{\text {nd }}$ Ed. Denver, 1996.

VOLK, C.; DUNDORE, E.; SCHIERMANN, J.; LECHEVALLIER, N. Practical evaluation of iron corrosion control in drinking water distribution system. Water Research, v. 34, n. 6, p. 1967-1974, 2000. http://dx.doi.org/10.1016/S0043-1354(99)00342-5

WORLD HEALTH ORGANIZATION - WHO. A manual on infection control in health facilities. New Delhi, 1988.

WORLD HEALTH ORGANIZATION - WHO. Health aspects of plumbing. Geneva, 2006.

WORLD HEALTH ORGANIZATION - WHO. Guidelines for drinking-water quality. $4^{\text {th }}$ Ed. Geneva, 2011. 